\title{
Pengaruh Metode Pembelajaran Pendidikan Agama Kristen Terhadap Prestasi Belajar Siswa Di Sekolah Dasar Negeri 002 Salueno Sulawesi Barat
}

\author{
Datu Paulus Kumba
}

\begin{abstract}
Abstrak
Tujuan penulisan skripsi adalah untuk menjelaskan pengaruh metode pembelajaran pendidikan Agama Kristen terhadap prestasi siswa di Sekolah Dasar Negeri 002 Salueno Sulawesi Barat. Adapun kesimpulan dari penelitian ini adalah sebagai berikut. Pertama, pada dasarnya metode sangat penting dalam proses belajar mengajar untuk meningkatkan prestasi belajar siswa demi tercapainya suatu tujuan yang diharapkan. Kedua, alasan penggunaan metode dalam mengajar karena adanya perbedaan, pemahaman, perbadaan pengalaman, situasi dan lingkungan belajar. Ketiga, metode pembelajaran yang digunakan oleh guru dalam mengajar itu sangat besar pengaruhnya terhadap siswa sehingga siswa mampu mengerti pelajaran yang diajarkan oleh guru disekolah dan bisa untuk berprestasi. Keempat, dalam belajar sangat dibutuhkan motivasi baik dari guru maupun dari orang tua siswa, sehingga siswa dapat belajar dengan baik, dan mampu mengaplikasikan setiap pelajaran yang diterima disekolah, untuk dikembangkan dan siswa bisa berprestasi sebagaimana yang diharapkan oleh guru maupun orang tua siswa itu sendiri. Kelima, dalam hal penerapan metode mengajar, dapat dikatakan sudah memenuhi kriteria-kriteria yang ada, seperti kemampuan dan keterampilan guru dalam menggunakan metode yang diterapkan, sehingga dapat membantu siswa untuk memahami pelajaran dengan baik.
\end{abstract}

Kata-kata Kunci: Metode Pembelajaran, Pendidikan Agama Kristen, Prestasi Belajar, Siswa, Sekolah Dasar. 


\section{Pendahuluan}

\section{Latar Belakang Masalah}

Pendidikan adalah sarana yang paling utama yang dibutuhkan oleh setiap manusia dimuka bumi ini, karena tanpa pendidikan manusia tidak akan bisa mengetahui situasi yang terjadi didunia globalisasi, pendidikan merupakan hal yang paling utama bagi setiap individu yang ada dimuka bumi. Karena tanpa pendidikan manusia tidak dapat berbuat apa-apa oleh karena itu pendidikan ini sangat bermafaat bagi setiap individu yang ada untuk dapat belajar semaksimal mungkin. "Pendidikan merupakan hal penting dalam kehidupan setiap orang, dan pandangan ini dapat diterima oleh seseorang jika telah mengerti dan memahami dengan benar tentang pendidikan itu sendiri. ${ }^{1}$

Menurut pendapat Radja Mudyahardjo diatas maka dapat disimpulkan bahwa dengan adanya pendidikan maka seseorang akan lebih mudah dalam hal belajar, sehingga mampu mengerti dan memahami dengan benar bahwa pendidikan itu sangat penting bagi kehidupan seseorang didalam menentukan masa depan yang lebih baik.

Kenyataan yang penulis lihat bahwa di SDN 002 Salueno pengajar sudah menggunakan metode atau suatu alat sarana sebagaimana yang diharapkan untuk mencapai target itu, dengan demikian anak-anak didik tersebut dapat menerima suatu pelajaran dengan baik dan terarah. Sebagai mana yang diungkapkan oleh B. Suryobroto bahwa: " Metode pengajaran adalah cara-cara pelaksana dari pada proses pengajaran, atau soal bagaimana teknisnya sesuatu bahan pelajaran diberikan kepada murid-murid disekolah. Jadi jelaslah bahwa metode adalah cara, yang dalam fungsinya merupakan alat untuk mencapai tujuan."

Dengan pemahaman diatas dapat disimpulkan bahwa metode dalam suatu pengajaran itu sangat penting dimana mengunakan teknik atau cara-cara sesuai dengan metode poses belejar mengajar kepada siswa untuk membantu sejauh mana kemampuan siswa dalam menerima materi pelajaran. Hal tersebut bahwa metode pengajarannya itu sendiri harus perlu dievaluasi supaya dapat melihat bahwa metode tersebut diterapkan dengan baik. sehingga apa yang diajarkan benar-benar bermanfaat. Dengan demikian materi yang diajar mudah dapat dimengerti dan dapat dipahami dengan jelas oleh anak didik sehingga siawa mampu untuk terapkan apa yang sudah diajarkan. karena dapat ditinjau dari metode pengajaran itu sendiri apabila

\footnotetext{
${ }^{1}$ Radja Mudyahardjo, Pendidikan Agama Kristen Konteks Indonesia (Bandung: Kalam Hidup, 2013) 21.

${ }^{2}$ Suryobroto, Metode Pengajaran di Sekolah dan Pendekatan Baru dalam Proses Belajar Mengajar (Yogyakarta: Yayasan ANDI, 1986), 3.
} 
sebagai seorang pengajar memberikan suatu pentunjuk yang jelas maka dengan sendirinya siswa mampu untuk mengingat kembali apa yang sudah diajarkan oleh pendidik kepada siswa. Dalam metode pengajaran. Sebagai pengajar dengan cara mengajar menggunakan metode itu sendiri supaya anak didik lebih teliti apa yang sudah diajakan, hal yang paling mudah untuk dimengerti oleh siswa Dapat ditinjau bahwa metode merupakan suatu alat atau sarana untuk mencapai target yang diharapkan. ${ }^{3}$ Dengan hal ini sebagai pengajar harus bisa menggunakan metode atau alat dalam metode pengajaran Karena metode itu sendiri selalu memberikan materi yang diajarkan itu sejalan atau terarah dan sebagai salah satu alat saja, bukan tujuan. ${ }^{4}$

Kenyataan yang terjadi di SDN 002 Salueno sudah mengunakan metode secara efektif di dalam mengajar sehingga tujuan yang diharapakan dapat berhasil, dalam proses belajar mengajar dapat berjalan dengan baik, karena cara mengajar sudah dengan baik terarah. sehingga anak didik dengan mudah menerima pelajaran sesuai dengan apa yang diharapkan. Dengan melihat masalah ini seorang pengajar harus lebih meningkatkan lagi cara mereka dalam mengembangkan cara mengajar yang lebih efektif sehingga siswa benar-benar menerima pelajaran sebagaimana yang diharapkan.

Konsep pemahaman yang terjadi di SDN 002 Salueno pengajarannya sudah berjalan dengan baik sebagaimana yang dharapkan. Siswa mampu mengerti pelajaran karena guru dapat menggunakan metode pada saat proses belajar mengajar berlangsung didalam kelas. Oleh karena itu proses belajar mengajar lebih ditingkatkan lagi agar setiap anak didik dapat menerima pelajaran dengan baik dan benar.

Penggunaan metode dalam proses belajar mengajar sangat penting sehingga guru harus dapat menentukan metode yang akan digunanakan. Agar setiap anak didik yang ada mampu menguasai pelajaran dengan baik, karena guru menggunakan metode sesuai dengan apa yang diharapkan sehingga dalam proses belajar mengajar metode yang digunakan dapat mencapai tujuan pembelajaran.

\section{Pokok Masalah}

Berdasarkan latar belakang di atas maka yang menjadi pokok masalah dalam skripsi ini adalah: Sejauh mana pengaruh metode pembelajaran Pendidikan Agama Kristen terhadap prestasi belajar siswa di Sekolah Dasar Negeri 002 Salueno Sulawesi Barat?

\section{Tujuan Penelitian}

\footnotetext{
${ }^{3}$ John M. Nainggolan, Guru Agama Kristen sebagai Panggilan dan Profesi (Bandung: Kalam Hidup, 2010),134.

${ }^{4}$ John M. Nainggolan, Guru Agama Kristen sebagai Panggilan dan Profesi, 134.
} 
Adapun tujuan yang hendak dicapai sehubungan dengan penulisan skripsi adalah: Menjelaskan pengaruh metode pembelajaran pendidikan Agama Kristen terhadap prestasi siswa di Sekolah Dasar Negeri 002 Salueno Sulawesi Barat.

\section{Metode Penelitian}

Dalam penulisan skripsi ini, penulis menggunakan metode penelitian kuantitatif dengan teknik pengumpulan data sebagai berikut:

Pertama, penulis melakukan kajian pustaka yaitu buku-buku dan jurnal yang berhubungan dengan metode pembelajaran PAK dan pendidikan kristen.

Kedua, penulis mengedarkan angket (kuesioner $)^{5}$ dengan pertanyaan tertutup kepada siswa siswi SDN 002 Salueno Sulawesi-Barat untuk mengetahui metode pembelajaran PAK.

Ketiga, penulis menggunakan angket dan wawancara yang ditujukan kepada kepala sekolah untuk mengenal lokasi penelitian.

\section{Batasan Penelitian}

Dalam penulisan skripsi ini, maka penulis akan membatasi penelitian dengan memfokuskan kepada metode pembelajaran PAK yang mempengaruhi prestasi akademik siswa SDN. 002 Salueno dan metode pembelajaran dalam meningkatkan prestasi belajar siswa SDN. 002 Salueno. Kelas 4-6.

\section{Manfaat Penelitian}

Hasil tulisan yang dituangkan dalam skripsi ini diharapkan dapat membawa manfaat sebagai berikut;

Pertama, agar karya tulis ini dapat memberkati, menambah wawasan penulis dan para pembaca.

Kedua, agar menjadi bahan acuan bagi sekolah SDN 002 Salueno dimana penulis mengadakan penelitian.

Ketiga, agar menjadi pedoman atau pegangan bagi penulis sendiri, menjadi pendidik dimasa mendatang.

Keempat, untuk memenuhi persyaratan penyelesaian tugas akhir untuk mencapai gelar sarjana pada Sekolah Tinggi Theologia Jaffray Makassar.

${ }^{5}$ Hengki Wijaya (ed.), Metodologi Penelitian Pendidikan Teologi (Makassar: Sekolah Tinggi Theologia Jaffray, 2016), 26. 


\section{Kepustakaan}

Mudyahardjo, Radja. Pendidikan Agama Kristen Konteks Indonesia. Bandung: Kalam Hidup, 2013.

Nainggolan, John M. Guru Agama Kristen sebagai Panggilan dan Profesi. Bandung: Kalam Hidup, 2010.

Suryobroto. Metode Pengajaran di Sekolah dan Pendekatan Baru dalam Proses Belajar Mengajar. Yogyakarta: Yayasan ANDI, 1986.

Wijaya, Hengki (ed.). Metodologi Penelitian Pendidikan Teologi. Makassar: Sekolah Tinggi Theologia Jaffray, 2016. 